MARIA DĘBOWSKA - LUBLIN

\title{
Archivum Ordinis Sancti Pauli Primi Eremitae - rozprawy i źródła do dziejów zakonu paulinów
}

W 1965 roku zakon paulinów (Ordo Sancti Pauli Primi Eremitae) świętował 750. rocznicę powstania ${ }^{1}$. Stała się ona okazją do zapoczątkowania dwóch serii wydawniczych: rozprawy (dissertationes) i źródła (fontes) pod wspólną nazwą: Archivum Ordinis Sancti Pauli Primi Eremitae. Inicjatorem i kontynuatorem prac nad tym dziełem jest ks. Stanisław Świdziński, paulin (imię zakonne: Sebastian), obecnie zaś duszpasterz w Niemczech (Coesfeld).

Pierwsza publikacja, która ukazała się w ramach wspomnianego wyżej wydawnictwa, należy do serii dissertationes. Zapewne z tego względu serii tej przypisano w kolejnych tomach numer I., chociaż fontes (oznaczone numerem II.) powinny znaleźć swoje właściwe miejsce przed rozprawami.

Dotychczas ukazało się sześć tomów dissertationes (łącznie 11 rozpraw i materiałów z konferencji naukowych) oraz 28 tomów fontes. Jako pierwsze $\mathrm{w}$ ramach serii dissertationes ukazały się w 1966 roku trzy rozprawy (w jednym tomie; każda publikacja posiada własną numeracją oprócz wspólnej, odnotowanej w nawiasach kwadratowych) ${ }^{2}$. Pozycja ta została wydana nakładem Instytutu Studiów Kościelnych w Rzymie (Institutum Studiorum Ecclesiasticorum, Roma, via Mecenate 37).

${ }^{1}$ „Paulini wywodzą się z rozproszonych w lasach pustelników węgierskich, zgromadzonych 1215-25 przez bpa Bartłomieja z Pecz”. J. Zbudniewek, Paulini, w: Encyklopedia katolicka, t. 15, red. E. Gigilewicz, Lublin 2011, kol. 83.

${ }^{2}$ S. Szafraniec, Konwent paulinów jasnogórskich 1362-1864, ss. 146, [s. 1-162]; G. Chedid, L'origine delle Costituzioni dell'Ordine Libanese Maronita, ss. 98 [s. 163-268]; M. Tumpić, Pavlini Varaždinci, ss. 31 [s. 269-303]. 
W ramach dissertationes ukazało się łącznie trzy tomy opracowań (8 rozpraw $)^{3}$ oraz trzy tomy zawierające materiały z międzynarodowych konferencji naukowych, poświęconych problematyce dotyczącej zakonu paulinów ${ }^{4}$.

Pierwszy tom serii fontes opublikowany został dopiero w 1973 roku (Augusta Trevirorum, Typographia ad S. Paulinum). W opracowaniu S. Świdzińskiego ukazały się wówczas konstytucje zakonu Paulinów - Constitutio Ordinis Pauli Primi Eremitae iuxta textum ante annum 1643 conscriptum. Historia - textus sententia. Po długiej przerwie, trwającej do 2006 roku, opublikowano dwa następne tomy fontes. Jeden z nich (Fontes, t. 2) został poświęcony konstytucjom dla klasztorów paulińskich w Polsce (1636). Podstawę edycji stanowił rękopis konstytucji (oficjalna kopia) przechowywany w archiwum klasztoru paulinów na Jasnej Górze. Tekst ukazał się w językach łacińskim i niemieckim.

Poczynając od 2006 roku, co roku - dzięki zaangażowaniu redaktora ks. S. Świdzińskiego i w jego opracowaniu - ukazuje się jeden lub więcej tomów paulińskich wydawnictw źródłowych. Są to edycje rękopisów bądź reprinty przeważnie starych druków z XVI-XVII w., odnoszących się do zakonu paulinów. Wydawane są przez Verlag Barmherziger Bund w Coesfeld, które to miasto jest obecnym miejscem pracy wydawcy tychże źródeł - ks. Stanisława Świdzińskiego.

W 2016 roku ukazał się 28 tom fontes. Zasługuje on na szczególną uwagę, gdyż jest to publikacja kroniki zakonu paulinów z lat 1864-1945 spisanej w latach 1942-1943 przez wieloletniego generała o. Piotra Markiewicza. Po kasacie, w 1864 roku, większości klasztorów paulińskich pod zaborem rosyjskim (Stara Częstochowa, Wieruszów, Wielgomłyny, Konopnica, Włodawa, Leśna, Leśniów, Konopiska), zaprzestano prowadzenia w klasztorze jasnogórskim akt prowincji polskiej, głównie z obawy przed prześladowaniami, jakie mogłyby dotknąć klasztor po ewentualnym przejęciu akt przez władze rosyjskie. Przez lata gromadzono jednak materiały z myślą o spisaniu kiedyś kroniki ex post. To dzieło zrealizował dopiero o. Piotr Markiewicz .

${ }^{3}$ Oprócz wspomnianego już wyżej pierwszego tomu, dwa pozostałe obejmują następujące rozprawy: T. IV/6: H. Czerwień, Druki Jasnogórskiej Oficyny w latach 1693-1863, Verlag Barmherziger Bund, Coesfeld 2006 (katalog druków); T. V/7-10, Verlag Barmherziger Bund, Coesfeld 2010: K. Kotnis, Życie duchowne według nauki o. Grzegorza Tereckiego, Kraków 1948 (przedruk), s. 2-61, Z. Rozanow, Z dziejów artystycznych Jasnej Góry, Kraków 1966 (przedruk), s. 63-139, S. Świdziński, De normis bibliothecis ordinandis in Constitutione Ordinis Sancti Pauli Primi Eremitae anno 1646 editae (dysertacja licencjacka, Roma 1966), s. 141-159, B. Degórski, Stan badań nad , Vita S. Pauli Primi Eremitae” św. Hieronima, Rzym 2010, s. 161-231.

${ }^{4}$ T. II/4: Beiträge zur Spiritualität des Paulinermönchtums. Internationale Tagung vom 12.14. September in Częstochowa, hg. von Stanisław Świdziński, Collectio Paulina im Kreisarchiv Bodenseekreis, Friedrichshafen 1999; T. III/5: Symposium zur Geschichte des Paulinerordens. Internationale Tagung vom 16.-20. Oktober in Zagreb, hg. von Stanisław Świdziński, Collectio Paulina im Kreisarchiv Bodenseekreis, Friedrichshafen 2005; T. VI/11: Ideologie des Paulinermönchtums Ende 15./ Anfang 16. Jahrhundert. Internationale Seminar im ehemaligen Paulinerkloster (13771786) vom 11.-15./16. Oktober 2010 in Marianka bei Bratislava, hg. von Stanisław Świdziński, Verlag Barmherziger Bund, Coesfeld 2012.

${ }^{5}$ Kronika, spisana przez o. Piotra Markiewicza, jest przechowywana w Archiwum Jasnej Góry, sygn. 2440, mps III - 169, a jej kopia w Archiwum na Skałce w Krakowie, sygn. B 228. 
Omawiana edycja Kroniki rozpoczyna się informacjami biograficznymi dotyczącymi kronikarza, paulina Piotra Markiewicza (s. V-VII), zaczerpniętymi ze słownika paulinów, opracowanego przez Józefa Stanisława Płatka OSPPE ${ }^{6}$. Wacław Markiewicz (1877-1961) urodził się w Kaliszu, w wielodzietnej rodzinie Józefa i Heleny ze Świerczyńskich. W 1902 roku wstąpił do zakonu paulinów na Jasnej Górze.. Habit zakonny otrzymał 16 lipca 1902 roku i rozpoczął nowicjat pod kierunkiem o Justyna Welońskiego. Wówczas otrzymał imię zakonne Piotr. Po pierwszej profesji (Jasna Góra, 16 lipiec 1903 roku) rozpoczął przygotowanie do kapłaństwa w seminarium duchownym we Włocławku. Święcenia kapłańskie przyjął 29 lipca 1906 roku. Studia w Rzymie, w latach 1906-1908, uwieńczył doktoratem $\mathrm{z}$ teologii. Pełnił różne funkcje w zakonie; był mistrzem nowicjatu, definitorem, przeorem klasztoru jasnogórskiego, a od 21 września 1920 roku przeorem generalnym (do 13 października 1931 roku). Po złożeniu urzędu generała zakonu, przeniósł się do Leśnej Podlaskiej, gdzie sprawował (do sierpnia 1940 roku) funkcje - najpierw podprzeora klasztoru, od 4 stycznia 1933 roku zaś - przeora i jednocześnie proboszcza tamtejszej parafii. Od sierpnia 1940 roku przebywał w klasztorze na Jasnej Górze, spełniając obowiązki wykładowcy w tajnym seminarium duchownym paulinów. W latach 1946-1952 pełnił ponownie urząd generała zakonu. Zmarł w klasztorze jasnogórskim 16 stycznia 1961 roku. Pozostawił po sobie (głównie w rękopisie) - oprócz kroniki - ponad dwadzieścia prac (nauki na różne uroczystości, konferencje, sprawozdania) ${ }^{7}$.

Kronikarz przedstawił niezwykle rzetelnie i uczciwie, dzieje paulinów (miejscami zabarwione subiektywizmem) od momentu kasaty większości klasztorów paulińskich do końca drugiej wojny światowej. Nie pominął również trudnych a nawet bardzo trudnych wydarzeń, które rozgrywały się w tym okresie. Najbardziej dramatycznym zdarzeniem w historii klasztoru jasnogórskiego było zabójstwo dokonane w jego murach przez paulina Damazego Macocha w 1910 roku. Biskup włocławski Stanisław Zdzitowiecki zdecydował się wówczas na wprowadzenie tam zarządu komisarycznego i naznaczył zakonnikom:

publiczną pokutę i to dotkliwą, piętnującą nas wobec społeczeństwa, mianowicie odsunął nas od ołtarza M.B. Częstochowskiej, na którym pozwalał odprawiać tylko jedną Mszę św. przed cudownym Obrazem odsłoniętym, podczas której nakazał wszystkim ojcom leżeć krzyżem w prezbiterium kaplicy. [...] Cała ta kara, w której raczej o wymienione efekty zewnętrzne, niż o ukaranie chodziło, trwała 3 miesiące $\mathrm{z}$ górą i gdy niebezpieczeństwo ze strony rządu minęło, a naród, poznawszy lepiej stan rzeczy, iż tylko trzech wymienionych ojców zostało skompromitowanych, uspokoił się. Biskup cofnął ją i odwoławszy komisarza swego z Jasnej Góry, całą władzę nad nią ojcom przywrócił (s. 34-35).

Wiele światła na kondycję duchową paulinów rzucają również informacje o przeprowadzanych reformach, które nie zawsze odnosiły pożądany skutek. Kronikarz odnotował także wiele podniosłych wydarzeń, m.in. jubileusz 500-lecia sprowadzenia na Jasną Górę cudownego obrazu Matki Bożej (wrzesień 1882 rok),

${ }^{6}$ J.S. Płatek, Dzieje paulinów XX wieku. Życie i działalność, Częstochowa 2003, s. 460-480.

${ }^{7}$ Wykaz tychże zob. Płatek, Dzieje paulinów XX wieku, s. 478-479. 
„imponująca” uroczystość poświęcenia odbudowanej po pożarze wieży kościelnej (15 sierpień 1906 rok), koronacja cudownego obrazu ,złotymi koronami, ofiarowanymi na prośbę arcybiskupa lwowskiego, Józefa Bilczewskiego przez Ojca św. Piusa X” (22 maj 1910 rok). Uroczystość ta, ,jak przystało na koronację Królowej narodu, odbyła się nadzwyczaj bogato i okazale, iście po królewsku” (s. 31).

Cennym uzupełnieniem edycji Kroniki (s. 1-99) są załączniki (6). Szczególną uwagę należałoby zwrócić na trzy pierwsze: I. O. Władysław Bohosiewicz redemptorysta (1868-1942) - wyjątki z opracowania Józefa Palewskiego odnoszące się do zakonu paulinów (s. 101-115), II. Breves normae religiose vivendi in Monasterio Cracoviensi Ordinis S. Pauli I-mi Eremitae (s. 120-144) - jest to reprint druku wydanego w Częstochowie w 1920 roku (w omawianym wydaniu dołączono również tłumaczenie tekstu łacińskiego na język niemiecki), III. Normy życia zakonnego dla klasztoru OO. Paulinów na Jasnej Górze, przepisane ad interim przez J.W. Księdza Biskupa dyecezyi kujawsko-kaliskiej - przedruk rozporządzeń wydanych we Włocławku (czcionkami Drukarni Diecezjalnej) w 1915 roku (s. 145-160).

W 1920 roku Stolica Apostolska mianowała redemptorystę Władysława Bohosiewicza wizytatorem całego zakonu paulinów (wcześniej był on wizytatorem konwentu na Skałce w Krakowie). Kronikarz odnotował, iż:

o. Bohosiewicz swą powagą Wizytatora Apostolskiego dużą był pomocą Zakonowi. Zwłaszcza w jego trudnościach wewnętrznych, powstających wtedy ze strony niektórych członków jego, lecz była to pomoc tylko, skuteczna i cenna, ale tylko pomoc. [...] będąc członkiem Zgromadzenia nowego, nie umiał wczuć się dosyć w ducha naszego Zakonu, toteż wpływ jego duchowy, zakonny na nasz Zakon, a zwłaszcza na Nowicjat i Klerykat odbywał się właśnie w duchu jego Zgromadzenia i całkiem odpowiednim dla nas nie był (s. 85).

Klasztor na Jasnej Górze znajdował się na terenie diecezji włocławskiej, której ordynariuszem był w latach 1902-1927 bp Stanisław Zdzitowiecki. Biskup sprawował władzę nad klasztorami w swojej diecezji za pośrednictwem wizytatora klasztorów; w czasie I wojny światowej pełnił tę funkcję ks. Władysław Krynicki. W tym czasie (z powodu zgorszenia spowodowanego zabójstwem) ordynariusz włocławski chciał nawet usunąć paulinów z Jasnej Góry (s. 37).

Edycję Kroniki poprzedza nota (w języku niemieckim) jej wydawcy (s. VIII-X) - ks. Stanisława Świdzińskiego. Należy jedynie żałować, iż niniejsze wydanie Kroniki nie zostało opatrzone aparatem naukowym w postaci przypisów.

Kronikę i inne publikacje z omawianego wydawnictwa można zakupić u ks. Stanisława Świdzińskiego w Coesfeld-Lette (Niemcy). 